\title{
Gambaran Penggunaan Bahan Restorasi Resin Komposit di Balai Pengobatan Rumah Sakit Gigi dan Mulut Universitas Sam Ratulangi Tahun 2011 - 2012
}

\author{
${ }^{1}$ Pingkan Sajow, ${ }^{2}$ A. J. M. Rattu, ${ }^{2}$ Dinar A. Wicaksono \\ ${ }^{1}$ Mahasiswa Program Studi Kedokteran Gigi Fakultas Kedokteran \\ Universitas Sam Ratulangi Manado \\ ${ }^{2}$ Dosen di Program Studi Kedokteran Gigi Fakultas Kedokteran Universitas Sam Ratulangi \\ Email : pinksajow@yahoo.co.id
}

\begin{abstract}
ABSTRAK
Karies gigi merupakan salah satu penyakit yang sering dialami oleh setiap individu. Perubahan tingkat ekonomi dan pola hidup menjadi beberapa penyebabnya. Kurangnya kesadaran masyarakat akan kesehatan gigi dan mulut juga menjadi salah satu penyebab karies pada gigi. Gigi yang karies sebaiknya segera dilakukan perawatan menggunakan salah satu bahan restorasi yang sering digunakan saat ini yaitu resin komposit.

Penelitian ini bertujuan untuk mengetahui gambaran penggunaan resin komposit sebagai bahan restorasi gigi di Balai Pengobatan Rumah Sakit Gigi dan Mulut (BP-RSGM) Universitas Sam Ratulangi pada tahun 2011-2012. Jenis penelitian ini merupakan penelitian deskriptif dengan pengambilan data berdasarkan rumus Slovin yang ditentukan dengan menggunakan teknik random sampling dari rekam medis pasien yang ditumpat dengan resin komposit di BP-RSGM pada tahun 2011-2012. Jumlah data penelitian yang diambil yaitu 85 pasien dengan 108 gigi yang direstorasi dan dikategorikan berdasarkan jenis kelamin, pekerjaan pasien, tahun restorasi, umur pasien, regio gigi, jumlah gigi dan diagnosa penyakit.

Hasil penelitian menunjukkan pada tahun 2012 telah terjadi peningkatan dalam penggunaan resin komposit dibandingkan pada tahun 2011. Perawatan dengan resin komposit lebih sering dilakukan oleh pasien yang berjenis kelamin perempuan dan sebagian besar telah berusia dewasa. Regio anterior merupakan regio gigi yang paling banyak mendapatkan restorasi dengan resin komposit dan penyakit gigi yang paling sering didiagnosa ialah pulpitis reversibel. Pada setiap pasien terdapat minimal 1 gigi yang ditumpat dengan resin komposit.
\end{abstract}

Kata kunci: Resin komposit, karies gigi

\section{ABSTRACT}

Dental caries is one of the most common sickness suffered by every people. Alterations in the economy and lifestyle are some of the causes. Lack of public awareness towards oral health is also one of the causes of dental caries. Dental caries should be taken care and one materials of the filling that are often used today is composite resin.

The purpose of this research is to know about the use of composite resin as restoration material in the Dental Clinic of Sam Ratulangi University in 2011-2012. This research is a descriptive retrospective research using the Slovin formulae and the random sampling technique approach by taking the medical records of patients at the Dental Clinic in 2011-2012 whom were given composite resin as the filling material. The amount of research data retrieved were of 85 patients with 108 teeth filled by composite resin and are categorized based of sex, patient activity, on the year of filling, age, region of filling, the number of teeth filled in each patient and diagnoses.

The results show that in the year of 2012 the use of composite resin restorations has increased in comparison to the year of 2011. Treatment with a composite resin is more often performed on female patients and most of them being adults. The anterior region of the teeth is the region most filled by composite resin and is most commonly diagnosed with pulpitis reversible. In each patient there is at least one tooth that is filled by composite resin.

Keywords: Composite resin, dental caries 


\section{Pendahuluan}

Pengetahuan akan kesehatan gigi dan mulut merupakan salah satu faktor penting dalam menunjang kesehatan suatu individu. Hasil Riset Kesehatan Dasar (Riskesdas) tahun 2007 menunjukkan bahwa Sulawesi Utara merupakan salah satu dari 5 provinsi yang memiliki nilai tertinggi dalam masalah kesehatan gigi dan mulut yaitu sebesar 29,8\%. Masalah kesehatan gigi dan mulut yang banyak ditemukan berupa kasus penumpatan gigi berlubang yaitu sebesar 35\%. ${ }^{1}$ Hal ini menunjukkan bahwa masih kurangnya kesadaran masyarakat akan kesehatan gigi dan mulut.

Dokter gigi sering melakukan penumpatan gigi berlubang yang diakibatkan oleh karies dengan menggunakan bahan tumpatan gigi. Tujuan dilakukannya penumpatan gigi yaitu untuk mencegah perluasan karies dan menjaga keutuhan struktur gigi yang tersisa. Beberapa bahan restorasi yang sering digunakan saat ini adalah amalgam, semen ionomer kaca dan resin komposit. ${ }^{2}$ Bahan restorasi yang baik dan dapat mengembalikan estetik merupakan kebutuhan masyarakat. ${ }^{3}$ Saat ini resin komposit menjadi pilihan utama dalam berbagai perawatan di bidang kedokteran gigi karena memiliki beberapa keunggulan seperti estetik yang baik, tidak mudah larut terhadap saliva dan tidak peka terhadap dehidrasi.

Bahan restorasi resin komposit relatif mudah dimanipulasi sehingga sangat membantu dokter gigi dalam melakukan perawatan gigi berlubang dan memberikan hasil yang memuaskan. Resin komposit digunakan sebagai restorasi di gigi yang memerlukan estetik dan restorasi pada pasien yang alergi atau sensitif terhadap logam. Penggunaan bahan adhesif resin komposit secara tepat sangat berperan dalam mencapai keberhasilan restorasi dan idealnya restorasi tersebut harus memberikan penutupan tepi restorasi yang sempurna serta bebas porositas. ${ }^{4}$

$$
\text { Penulis melakukan }
$$

penelitian di Balai Pengobatan Rumah Sakit Gigi dan Mulut (BPRSGM) Universitas Sam Ratulangi (UNSRAT) pada periode tahun 2011 sampai tahun 2012 
berdasarkan, jenis kelamin, pekerjaan, tahun restorasi, usia, regio gigi, jumlah gigi, dan diagnosa penyakit pada setiap pasien yang giginya direstorasi dengan resin komposit. BP-RSGM UNSRAT merupakan rumah sakit yang dikelola oleh Universitas Sam Ratulangi yang diresmikan pada tahun 2010. Tujuan pembangunan rumah sakit ini adalah dalam rangka mewujudkan cita-cita dan harapan dalam menyelenggarakan pelayanan kesehatan bagi penduduk yang ada di wilayah Manado dan sekitarnya, serta merupakan lahan praktek bagi mahasiswa tahap profesi di Program Studi Kedokteran Gigi Fakultas Kedokteran Universitas Sam Ratulangi. Pelaksanaan kurikulum program Pendidikan Profesi (dokter gigi) di Rumah Sakit Gigi dan Mulut (RSGM) dilakukan setelah pendidikan tahap sarjana kedokteran gigi.

Pada zaman yang semakin modern ini sesuai dengan perkembangan teknologi, resin komposit banyak dipilih oleh pasien karena memiliki beberapa kelebihan dibanding dengan bahan restorasi lainnya yaitu estetiknya lebih baik, lebih kuat, lebih keras, penyerapan air dan penyusutannya kecil, tidak mudah mengalami abrasi dan mudah dimanipulasi. Hal ini yang menyebabkan cukup banyak pasien yang datang berobat di BP-RSGM Universitas Sam Ratulangi yang tertarik untuk menggunakan tumpatan resin komposit sebagai bahan restorasi gigi yang juga memenuhi syarat untuk diteliti perkembangannya. Melalui penelitian ini, diharapkan dapat mewakili data penggunaan resin komposit sebagai bahan restorasi gigi pada pendidikan kedokteran gigi tahap profesi atau kepanitraan klinik di Prodi KG FK UNSRAT.

\section{Pembahasan}

\section{Hasil Penelitian}

Penelitian berlangsung selama tiga bulan. Pengambilan data menggunakan teknik random sampling yang dilakukan di bagian administrasi BP-RSGM Universitas Sam Ratulangi dengan subjek penelitian yaitu rekam medis dari pasien yang direstorasi resin komposit pada tahun 2011 dan tahun 2012 berjumlah 551 pasien, akan tetapi mewakili data yang ada maka setelah perhitungan menggunakan rumus Slovin jumlah 
sampel yang diteliti berjumlah 85 pasien dengan 108 gigi. Hasil penelitian mengenai penggunaan resin komposit berdasarkan jenis kelamin, pekerjaan pasien, tahun restorasi, umur pasien, regio gigi, jumlah gigi dan diagnosa penyakit:

1. Distribusi frekuensi berdasarkan jenis kelamin

Berikut ini ialah hasil penelitian mengenai distribusi penggunaan resin komposit berdasarkan jenis kelamin pasien (Gambar 5).

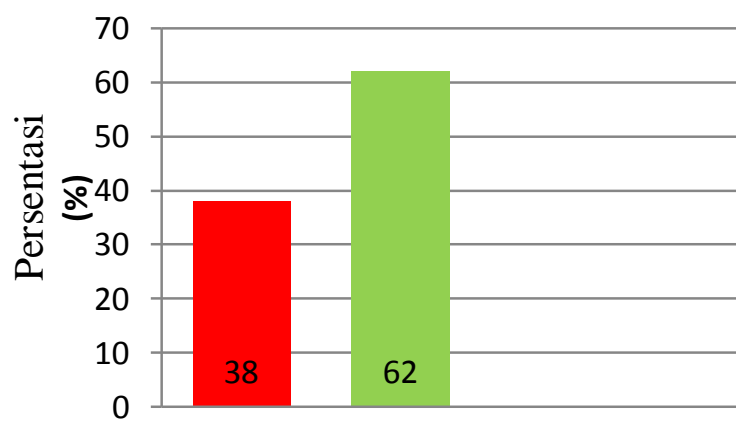

Laki-laki Perempuan

Jenis kelamin

2. Distribusi frekuensi

berdasarkan pekerjaan

Berikut ini hasil penelitian mengenai distribusi penggunaan resin komposit berdasarkan pekerjaan pasien (Gambar 6).

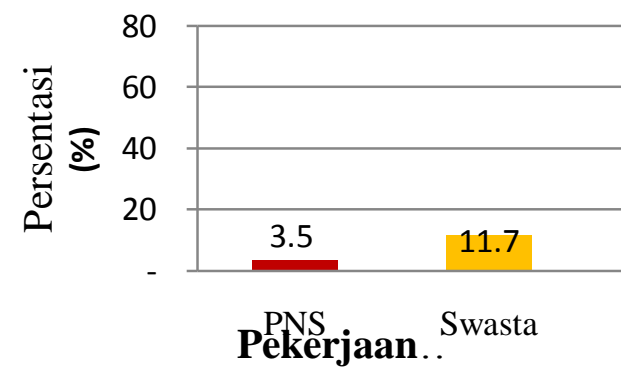

3. Distribusi frekuensi berdasarkan tahun restorasi Berikut ini adalah data yang diambil untuk penelitian yaitu tahun 2011 dan tahun 2012 (Gambar 7).

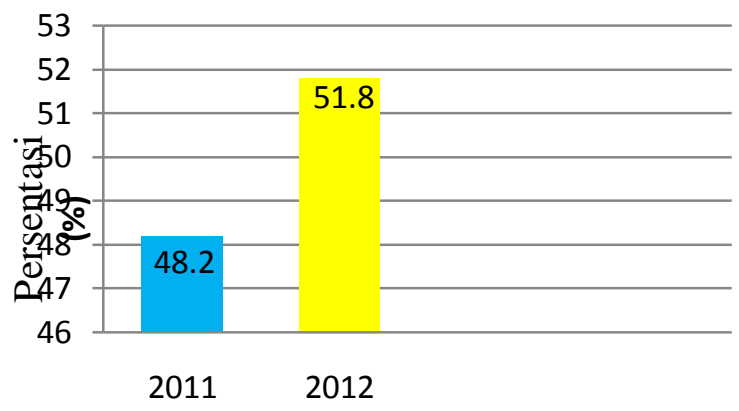

Tahun restorasi

4. Distribusi frekuensi berdasarkan usia pasien Berikut ini ialah hasil penelitian mengenai distribusi penggunaan resin komposit berdasarkan kelompok usia pasien (Gambar 8).

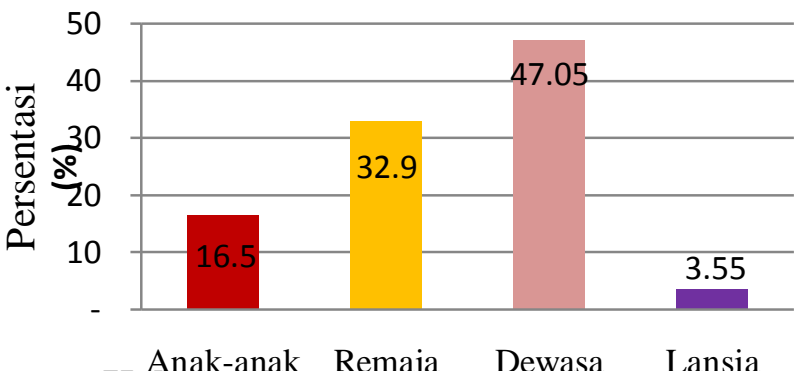
Kelompok usia..

5. Distribusi frekuensi berdasarkan regio gigi yang direstorasi

Berikut ini hasil penelitian mengenai distribusi penggunaan resin komposit berdasarkan 
regio gigi yang direstorasi (Gambar 9).

\section{Distribusi}

frekuensi

berdasarkan jumlah gigi

Berikut ini ialah hasil penelitian mengenai distribusi penggunaan resin komposit berdasarkan jumlah gigi yang direstorasi dengan resin komposit pada tiap pasien (Gambar 10).

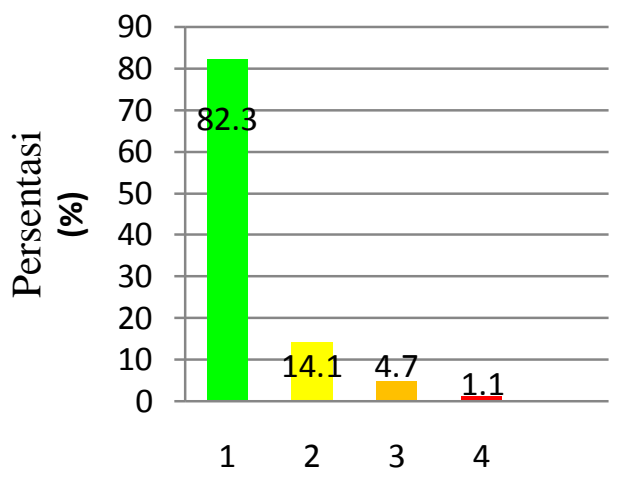

\section{Jumlah gigi}

7. Distribusi

frekuensi

berdasarkan

diagnosa

penyakit

Berikut ini ialah hasil penelitian mengenai distribusi penggunaan resin komposit berdasarkan diagnosa penyakit (Gambar 11).

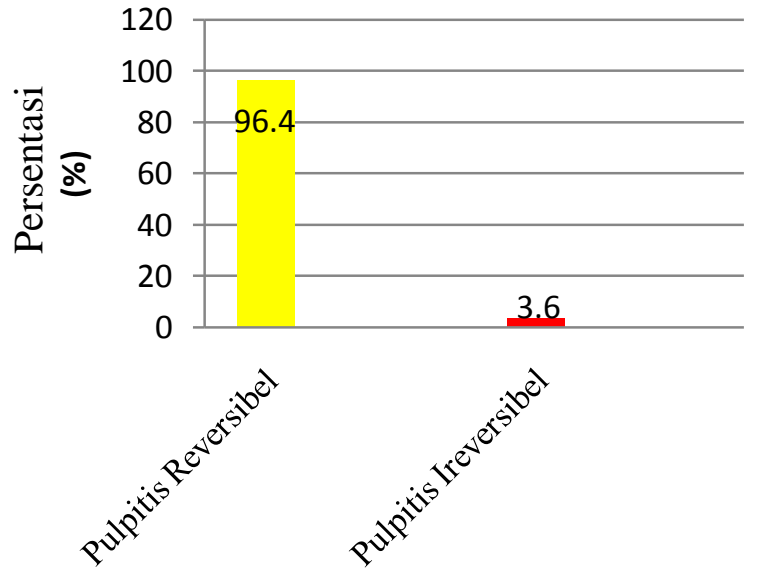

Diagnosa Penyakit

Berdasarkan jenis kelamin, pasien perempuan merupakan kelompok yang paling banyak mendapatkan perawatan restorasi resin komposit di BPRSGM Universitas Sam Ratulangi yaitu sebanyak $62 \%$ dibandingkan kelompok pasien laki-laki sebanyak $38 \%$.

Hasil penelitian yang sama juga dilaporkan oleh Soncini dkk di Inggris bahwa kelompok pasien perempuan lebih banyak menggunakan bahan tumpatan resin komposit yaitu sebesar $58,4 \%$. Bagi kaum perempuan, kesehatan dan penampilan merupakan hal yang paling penting. Bukan hanya penampilan dan kesehatan fisik saja, tetapi kesehatan dan penampilan gigi dan mulut juga tidak kalah penting untuk dijaga dan dirawat. Gigi yang sehat serta memiliki estetik yang baik merupakan hal yang sangat menunjang dalam penampilan kaum perempuan dan berpengaruh juga dalam 
meningkatkan rasa kepercayaan diri.

Memiliki gigi yang rusak akibat karies, tentunya membuat perempuan merasa tidak nyaman akan kesehatan giginya dan rasa kepercayaan diri akan menurun. Apabila hal tersebut terjadi, para perempuan akan langsung pergi ke dokter gigi untuk mendapatkan perawatan bagi gigi yang bermasalah. Dan salah satu perawatan yang paling diminati bagi perempuan adalah resin komposit karena memiliki estetik yang baik bila dibandingkan dengan bahan tumpatan lain. Jika dibandingkan dengan laki-laki yang cenderung tidak terlalu peduli terhadap penampilan maupun kesehatan gigi dan mulutnya. Sebagian besar lakilaki sudah merasa puas akan penampilan dan kondisi kesehatan gigi dan mulutnya. Hal ini sesuai dengan hasil survei yang dilakukan oleh American Dental Association (ADA) yang menyatakan bahwa kaum perempuan $89 \%$ lebih rutin ke dokter gigi untuk merawat giginya dibandingkan laki-laki $75 \%$. Perempuan pada umumnya lebih rentan terhadap masalah kesehatan gigi karena adanya perubahan hormonal yang mereka alami. ${ }^{34}$

Perubahan hormonal dapat mempengaruhi aliran darah ke jaringan gingiva dan mempengaruhi respon tubuh terhadap toksin yang dihasilkan oleh plak. Perubahan hormonal mengakibatkan perempuan menjadi lebih rentan terhadap penyakit jaringan periodontal (jaringan penyangga gigi) dan karies gigi pada waktu tertentu dalam hidupnya. Salah satu fase dalam hidup seorang perempuan dimana terjadi perubahan hormonal yang dapat mengakibatkan dirinya menjadi lebih rentan terhadap masalah kesehatan gigi dalam hal ini karies gigi, yaitu fase menopause. Manifestasi oral akibat menopause dan paska menopause meliputi penurunan saliva yang bisa menyebabkan proses karies meningkat. Menurunnya jumlah hormone estrogen yang terjadi pada masa menopause menyebabkan kaum perempuan memiliki resiko lebih tinggi untuk kehilangan densitas tulang. Kehilangan densitas tulang terutama pada rahang dapat mengakibatkan terjadinya gigi goyang. Resesi gingiva juga merupakan tanda kehilangan tulang pada rahang. Resesi gingiva dapat mengakibatkan lebih terbukanya permukaan gigi sehingga berpotensi terjadinya karies gigi. ${ }^{35}$

Berdasarkan pekerjaan pasien yang datang di BPRSGM Universitas Sam Ratulangi, kelompok yang paling banyak mendapatkan perawatan restorasi resin komposit adalah pelajar yaitu 
sebanyak 75,3\%. Diikuti dengan pekerja swasta sebanyak $11,7 \%$, sedangkan PNS 3,5\%, pensiunan $1,1 \%$, dan yang tidak memiliki pekerjaan berjumlah $8,4 \%$. Hal ini disebabkan karena sebagian besar pelajar belum memiliki penghasilan sendiri, oleh sebab itu pelajar mencari tempat perawatan gigi dengan harga yang cukup terjangkau bahkan gratis karena adanya ajakan dari beberapa mahasiswa co-ass untuk menyelesaikan kasuskasus tertentu yang menggunakan resin komposit.

Berdasarkan tahun restorasi, penggunaan resin komposit sebagai bahan restorasi gigi meningkat di tahun 2012 yaitu berjumlah 51,8\% dibandingkan pada tahun 2011 yaitu sebanyak 48,2\%. Dari data yang tercatat pada buku kontrol pasien di BP-RSGM Universitas Sam Ratulangi menunjukkan bahwa penggunaan resin komposit sebagai bahan restorasi gigi meningkat dari tahun ke tahun. Pada tahun 2012 pemakaian resin komposit mengalami peningkatan yang cukup besar karena pemakaian amalgam yang sudah mengalami penurunan. Bahan amalgam yang memiliki nilai estetik kurang dan adanya merkuri yang terkandung dalam amalgam serta kekurangan lainnya yang menjadikan tingkat kepuasan pasien terhadap bahan amalgam menurun. Hal ini yang menjadi salah satu alasan pasien lebih memilih bahan resin komposit sebagai bahan restorasi gigi daripada amalgam.

Berdasarkan usia pasien, menunjukkan bahwa pasien yang berusia dewasa berjumlah 47,05\% lebih sering melakukan perawatan restorasi resin komposit dibandingkan usia remaja 32,9\%, anak-anak 16,5 $\%$ dan lansia 3,55\%. Pada kelompok usia anak-anak sampai remaja biasanya kurang memperhatikan penyakit yang ada dalam rongga mulut, salah satunya karies. Mereka cenderung membiarkan keadaan giginya yang karies bila tidak ada rasa sakit. Sedangkan pada kelompok usia lansia, kesehatan gigi dan estetiknya juga kurang diperhatikan. Kalaupun ada gigi mereka yang rusak, biasanya mereka lebih memilih untuk mencabut gigi mereka dan menggunakan gigi tiruan atau protesa.

Berdasarkan hasil penelitian, regio gigi yang ditumpat menunjukkan bahwa restorasi dengan resin komposit banyak dilakukan pada regio gigi anterior yang berjumlah 54,1 \% dibandingkan pada regio gigi posterior yang berjumlah $52,9 \%$. Hal ini disebabkan oleh nilai estetik yang lebih mudah terlihat pada regio anterior dibandingkan regio posterior. Pada regio anterior yang paling sering menggunakan restorasi 
resin komposit adalah gigi insisivus pertama, sedangkan regio posterior yang sering menggunakan resin komposit yaitu gigi molar pertama. Hal ini disebabkan karena gigi molar menerima beban kunyah yang paling besar karena hampir setiap saat gigi ini digunakan untuk mengunyah makanan.

Gigi molar lebih rentan terkena karies dibandingkan gigi premolar maupun gigi yang berada di regio anterior. Gigi molar pertama jauh lebih rentan terhadap karies dibandingkan gigi lain karena juga merupakan gigi yang pertama kali erupsi. Hasil penelitian menunjukkan gigi molar pertama merupakan gigi yang mudah terserang karies dengan persentase 66-88 $\%$ diantara semua gigi. Gigi geligi dan permukaan gigi yang beresiko tinggi terkena karies adalah pit dan fissure gigi molar. Pit dan fissure pada gigi molar yang memudahkan retensi makanan dan merupakan tempat ideal bagi pertumbuhan bakteri karies. Terdapat kesulitan untuk membersihkan dengan baik pada daerah pit dan fissure gigi molar memakai sikat gigi, karena sebagian besar bagian dalam pit dan fissure tidak dapat dicapai dengan bulu sikat gigi sehingga menjadi salah satu penyebab gigi molar mudah terkena karies dibandingkan gigi lainnya. ${ }^{37}$

Berdasarkan jumlah gigi yang direstorasi pada tiap pasien menunjukkan bahwa jumlah gigi yang paling banyak dilakukan restorasi pada tiap pasiennya ialah berjumlah 1 gigi (82.3\%) dibandingkan dengan jumlah 2 gigi (14,1\%), 3 gigi $(4,7 \%)$, dan 4 gigi $(1,1 \%)$. Untuk pasien yang mendapatkan perawatan tumpatan resin komposit sejumlah 2 gigi hingga lebih, terdapat tumpatan yang dilakukan hanya pada satu regio dan juga pada kedua regio. Di dalam rongga mulut pada setiap individu terdapat banyak bakteri dan kuman yang bisa menyebabkan kerusakan pada gigi, salah satunya ialah karies.Ini disebabkan karena pola hidup yang kurang memperhatikan kebersihan dari gigi dan rongga mulut. Inilah yang dapat menjadi beberapa faktor yang menyebabkan setiap individu berpotensi terserang penyakit karies gigi. ${ }^{37}$

Berdasarkan diagnosa penyakit, pulpitis reversibel merupakan penyakit yang paling banyak didiagnosa dan paling banyak mendapatkan perawatan restorasi resin komposit yaitu sebesar 96,4\%, sedangkan pulpitis ireversibel 3,6\%. Pulpitis reversibel merupakan proses inflamasi ringan yang apabila penyebabnya dihilangkan maka inflamasi dapat hilang dan pulpa akan kembali normal. Penyebab rasa sakit pada kasus pulpitis reversibel umumnya 
peka terhadap suatu stimulus, seperti air dingin atau aliran udara. Karena pulpa sensitif terhadap perubahan temperatur terutama dingin, aplikasi dingin merupakan salah satu cara untuk menemukan diagnosa gigi yang terlibat. ${ }^{38}$

$$
\text { Pulpitis }
$$

reversibel

simtomatik ditandai dengan rasa sakit tajam.Lebih sering diakibatkan oleh makanan dan minuman yang dingin. Tidak timbul spontan dan tidak berkelanjutan bila penyebabnya dihilangkan. Pulpitis reversibel asimtomatik dapat disebabkan karena karies yang baru dan menjadi normal kembali setelah karies dihilangkan dan gigi direstorasi dengan baik.Salah satu penyakit yang termasuk dalam pulpitis reversibel ialah hiperemia pulpa. ${ }^{38}$

Hiperemia

pulpa

merupakan suatu permulaan radang yang ditandai oleh pertambahan aliran darah dalam rongga pulpa dan pelebaran pembuluh darah sebagai reaksi akibat adanya iritasi terhadap pulpa. Hiperemia pulpa ada dua tipe, yang pertama ialah hiperemia pulpa arterti (aktif) yaitu terjadinya peningkatan peredaran darah arteri dan hiperemia pulpa vena (pasif) yaitu terjadinya pengurangan peredaran darah vena. Hiperemia pulpa bisa diakibatkan karena trauma, seperti oklusi traumatik dan syok termal sewaktu preparasi kavitas atau reaksi kimiawi, seperti makanan yang asam atau manis, iritasi terhadap bahan tumpatan, serta bahan sterilisasi dentin (fenol, $\mathrm{H}_{2} \mathrm{O}_{2}$, alkohol, kloroform) bisa menyebabkan hiperemia pulpa sehingga penyakit ini mudah didiagnosa. Penyebab lainnya yaitu bakteri yang dapat menyebar melalui lesi karies atau tubulus dentin ke pulpa. Hiperemia pulpa bersifat reversibel dan dapat disembuhkan dengan cara menghilangkan rangsangan penyebabnya. ${ }^{39}$

Hiperemia pulpa memiliki kedalaman karies mencapai dentin atau perbatasan email dan dentin. Karies yang sudah mencapai bagian dentin atau bagian pertengahan antara permukaan gigi dan pulpa, biasanya gigi akan terasa sakit apabila terkena rangsangan dingin, makanan masam dan manis. Apabila pembusukkan telah mencapai dentin, maka bagian gigi yang membusuk harus diangkat dan diganti dengan tumpatan. Hiperemia pulpa didiagnosis melalui gejalanya dan pemeriksaan klinis. Rasa sakit tajam dan berdurasi pendek yang berlangsung beberapa detik sampai kira-kira 1 menit umumnya hilang jika rangsangan disingkirkan. Pemeriksaan visual dan riwayat sakit pada gigi tersebut harus 
diperhatikan, misalnya apakah terdapat karies, gigi pernah ditumpat, serta terdapat fraktur pada mahkota gigi atau oklusi traumatik. Hiperemia pulpa harus dibedakan dengan hipersensitivitas dentin walaupun keduanya termasuk pulpitis reversibel. ${ }^{40}$

\section{Kesimpulan}

1. Penggunaan bahan restorasi resin komposit di Balai Pengobatan Rumah Sakit Gigi dan Mulut Universitas Sam Ratulangi pada tahun 2012 mengalami peningkatan dibandingkan tahun 2011.

2. Pekerjaan pasien yang melakukan perawatan restorasi resin komposit yang paling banyak yaitu pelajar kemudian diikuti pekerjaan lainnya.

3. Perawatan restorasi resin komposit lebih banyak dilakukan pasien perempuan dibandingkan dengan laki-laki.

4. Penggunaan bahan restorasi resin komposit yang paling banyak pada pasien yang berusia dewasa dibandingkan dengan kategori usia lainnya.

5. Regio gigi yang lebih banyak mendapatkan perawatan yaitu regio anterior dibandingkan dengan regio posterior.

6. Jenis penyakit yang paling sering didiagnosa pada rekam medis pasien yaitu pulpitis reversibel dibandingkan diagnosa lainnya.

\section{Saran}

1. Perlu dilakukan penelitian lebih lanjut mengenai gambaran penggunaan bahan restorasi resin komposit pada instansi kesehatan lainnya yang ada di kota Manado sebagai data pembanding terhadap hasil penelitian ini.

2. Perlu dilakukan penelitian dengan sampel yang lebih besar agar dapat diperoleh data statistik yang lebih luas di kota Manado maupun di luar kota Manado mengenai jenis bahan restorasi resin komposit.

3. Untuk BP-RSGM Universitas Sam Ratulangi, diharapkan dapat meningkatkan pemberian edukasi tentang pentingnya menjaga kesehatan gigi dan mulut dan pencegahan penyakit mulut khususnya karies gigi serta memberikan 
informasi yang cukup tentang pemilihan bahan restorasi yang sesuai kepada pasien.

4. Untuk peneliti dalam melakukan penelitian selanjutnya, dapat meneliti lebih dari satu bahan restorasi gigi.

\section{DAFTAR PUSTAKA}

1. Soendoro T. Laporan hasil riset kesehatan dasar nasional. Badan Penelitian dan Pengembangan Kesehatan; 2007; hal.130-131.

2. Indriani. Survei pemaparan penggunaan amalgam, GIC dan resin komposit sebagai bahan tumpat gigi di RSGM FKG UI pada tahun 2005, 2006, dan 2007. Fakultas Kedokteran Gigi Universitas Indonesia; 2008.

3. Putri GM. Perubahan Pola Hidup Sebabkan Gigi Berlubang. [online]. 2012 [cited 2012 Mar 15]; Available from URL:

http://health.okezone.com/read/2 012/03/01/482/585501/perubaha n-pola-hidup-sebabkan-gigiberlubang

4. Alabik F. Merawat Serta Menjaga Kesehatan Gigi dan Mulut dengan Herbal. [online]. 2011 [cited 2012 Mar 15]; Available from URL: http://alabik.com/merawat-sertamenjaga-kesehatan-gigi-danmulut-dengan-herbal.html
5. Hermina T. Perbaikan Restorasi Resin Komposit klas I. [online]. 2003. [cited 2012 Mar 15]; Available from URL: http://repository.usu.ac.id/bitstre am/123456789/1180/1/fkghermina4.pdf

6. Susanty H. Tambalan Estetik Komposit. [online]. 2010. [cited 2012 Mar 15]; Available from URL:

http://www.dentiadental.com/20 10/articles/tambalan-estetikkomposit/

7. Noerdin A. Kemampuan Lekat Resin Komposit Pada Reparasi Restorasi Porselen Yang Fraktur. Jurnal Kedokteran Gigi Universitas Indonesia. 2000. hal. 7:94.

8. Baum, Phillips, Lund. Buku ajar ilmu konservasi gigi. ed 3. Alih bahasa: Rasinta Tarigan, Jakarta: EGC. 1994. hal. 251-99.

9. Irawan B. Komposit Berbasis Resin Untuk Restorasi Gigi Posterior. Dentika Dental.2005;10. hal.126-131.

10. Irawan B. Material Restorasi Direk Kedokteran Gigi Saat Ini. Jurnal Kedokteran Gigi Indonesia. 2004;11 (1). hal. 26.

11. Garcia AH, Lozano MAM, Vila JC, Escribano AB, Galve PF. Composite resin: a review of the materials and clinical indications. Med oral patol oral cir bucal 2006;11. p. 215-20.

12. Anusavice KJ. Phillips science of dental material. $11^{\text {th }}$ ed. St. 
Louis: Elsevier, 2003. p. 399435.

13. McCabe JF, Walls AWG. Applied Dental Materials. $9^{\text {th }}$ ed. Australia: Blackwell, 2008. p. 197-224.

14. Bowman C. Stansbury J. Building a Better Dental Composite. 2006. National Institute of Dental and Craniofacial Research.

15. Roberson TM; Heymann HO; Swift EJ. Sturdevant's Art \& Science of Operative Dentistry $4^{\text {th }}$ ed. 2002. Missouri: Mosby Inc.

16. Sularsih S. Penggunaan resin komposit untuk mengurangi resiko barodontalgia. Jurnal Kedokteran Gigi. 2007:1(2): hal. 102-105.

17. Arifin D. Indikasi dan Cara Aplikasi Berbagai Tipe Resin Komposit Yang Beredar Di Pasaran. Jurnal Kedokteran Gigi. 2006;vol 18: hal. 19-25.

18. O' Brien W. Dental Material and their selection. $3^{\text {th }}$ ed. Quintessence inc, 2002. p. 1136, 123-129.

19. Puckett AD, Fitchie JG, Kirk PC, et al. Direct Composite Restorative Materials. Dent Clin $\mathrm{N}$ am. 2007; 51: p. 659-75.

20. Navegar. The Dental Board of California, Dental Materials fact sheet. [online]. 2005. [cited 2012 apr 7]; Available from URL:
http://UCLA.edv/pasientcare/De ntal_Materials_fact_sheet.pdf.

21. Margeas RC. Composite restoration esthetic. The academy of dental theraupetics and stomatology; 2005; p.2-8.

22. Anusavice KJ. Phillips: buku ajar ilmu bahan kedokteran gigi. ed.10. Alih bahasa: Johan Arief Budiman, Susi Purwoko. Jakarta: EGC, 2003; 194-255.

23. Taqwim A. Restorasi preventif resin sebagai alternative restorasi pencegahan karies pada pit dan fisur. [online]. 2011. [cited 2012 Apr 7]; Available from:

http://dentosca.wordpress.com/2 011/06/13/restorasi-preventifresin-pada-pit-dan-fisur/

24. Saparatos. Resin komposit. [online]. 2011. [cited 2012 Apr 7]; Available from: http://doktergigibaik.wordpress. com/2011/03/29/resumependahuluan-resin-komposit/.

25. Hartono R, Kosasih A, Hidayat H. Estetik dan prostetik mutakhir kedokteran gigi. Jakarta:EGC, 1992; hal.84-5.

26. Anusavice KJ. Phillip's science dental materials. $11^{\text {th }}$ ed. Philadelphia: WB Saunders Co, 2003: 363-71, p. 399-426.

27. Lohbauer U, Miller FA, Petschelt A. Influence of surface roughness on mechanical strength of resin composite versus glass ceramic materials. J Dent Mater. 2008; 24: p. 350-6. 
28. Reis AF, Giannini M, Lovadino JR, Ambrosano GM. Effect of various finishing system on the surface roughness and staining susceptibility of pack-able composite resin. J Dent Mater. 2002; 19: p. 12-8.

29. Strassler HE. Predictable restoration of posterior teeth with composite resin. University of Maryland Dental School; 2009; p.98-104.

30. Morgan M. Finishing and polishing of direct posterior resin restorations. Pract Proced Aesthet Dent. 2004; 16(3): hal. 211-216.

31. Choi MS, Lee YK, Lim SB, Rhee SH, Yang HC. Changes in surface characteristics of dental resin composites after polishing. $\mathrm{J}$ Mater science: Materials in medicine. 2005; 16: p. 347-53.

32. Heintze SD, Forjanic M, Rousson V. Surface roughness and gloss of dental materials as a function of force and polishing time in vitro. $J$ Dent Mater. 2006; 22: p. 146-45.

33. Rusli A, Rasad A, Enizar, Irdijiati I, Subekti I, Suprapta IP, Mohammad K, Adam K, Luwiharsih, Santoso O, Oewen RR, Sjamsuhidajat, Alwy S, Sirie S, Akbar SMS. Manual Rekam Medis. Konsil Kedokteran Indonesia; 2006:3

34. Anonim. Komposit nano hibrid. [image on the Internet]. c2009. [Cited 2012 Apr 10]. Available from

URL: http://www.google.co.id/imgres? $\mathrm{q}=$ resin+komposit+hibrid\&start)

35. Cohen S, Richard C. Burns. Pathways of the pulp. $9^{\text {th }}$ Ed. St. Louis: Mosby. 2004. p. 21-23.

36. Hegenbarth EA. Creative color system. Chicago: Quintessence. 1989

37. Anonim. Proses polimerisasi komposit. [online]. 2006. [cited 2012 Apr 7]; Available from URL:

http://gigisehatbadansehat.blogs pot.com/2010/02/tentangshrinkage-komposit.html

38. Pradhana MY. Polimerisasi resin komposit. [online]. 2009. [cited 2012 May 23]; Available from URL: http://dhanajournal.blogspot.co $\underline{\mathrm{m} / 2009 / 06 / \text { polimerasi-resin- }}$ komposit.html

39. Dentisha. Pulpitis reversibel, ireversibel dan nekrosis pulpa [online]. 2010. [cited 2012 Juli 17]; Available from URL: http://luv2dentisha.wordpress.co $\mathrm{m} / 2010 / 05 / 08 /$ pulpitisreversibel-ireversibel-nekrosispulpa/

40. Health Care Center. Hiperemia pulpa [online]. [cited 2012 juli 17]; Available from URL: http://www.oborku.com/index.p hp?lang=IN\&mib=penyakit.deta $\underline{\text { il\&id=2009120717481801. }}$. 